\title{
Is Good Governance an Approach to Civil Service Reforms?
}

\author{
MUHAMMAD IQBAL
}

\section{INTRODUCTION}

The Civil Service refers to the body of officials who carry out functions of government under the direction and supervision of the head of government [Rahman (1998), p. 2]. Excluded in this definition are employees of state-owned enterprises, the army, teachers, the judiciary and the police who, together with civil servants, collectively constitute the public sector. It is the civil service, and not the public sector, which will be the focus of this paper.

Civil Service arrangements have emerged as important mediating institutions which interface between the state and its citizens. Traditionally these were monolithic, centralised, powerful structures with immense power over the management of the affairs of a nation, and often not very responsive to the changing needs of governance and public management.

However, in recent times many governments have realised the importance of greater efficiency (both economic and functional) in the delivery of services to their citizens. Thus governments in different parts of the world have initiated large-scale reform in their civil services to achieve greater efficiency, effectiveness and responsiveness.

\section{MODES OF GOVERNANCE}

In practice good governance involves promoting the rule of law, tolerance of minority and opposition groups, transparent political processes, an independent judiciary, an impartial police force, a military that is strictly subject to civilian control. A free press and vibrant civil society institutions, as well as meaningful elections. Above all, good governance means respect for human rights.

The three modes of governance considered are governance through state authority and governance through the market. These modes are self-explanatory in themselves, so I will go through them very briefly.

\section{Governance through State Authority}

This concept of governance is the most widely known form of governance and it is particularly relevant to our society, where the government is the major constitutive

Muhammad Iqbal <iqbalarfeen@gmail.com> is a Doctoral Research Fellow and is associated with Civil Aviation Authority, CAA, Karachi. He is a member of the PSDE, American Management Association, Pakistan Institute of Management, Chartered Institute of Logistic and Transport. 
element of the governance process. It underlines the important role of the state/government in providing the regulatory environment and institutional underpinning to facilitate efficient market exchange. For example, without courts to interpret and enforce agreements, commercial life would become chaotic; without laws to define, and police and courts to enforce them, property rights would be non-existent. Thus, governance through this mode takes place through the interplay of a host of institutional arrangements and policy strategies that the state puts in place.

Thus, state governance cuts across all modes of governance and is central to the effectiveness of the entire system of governance.

\section{Governance through the Market}

The most basic form of governance here is through the forces of competitive markets, i.e., through market exchange and the price mechanism. Under this mode, therefore, the balance of governance and coordinating functions shifts towards greater reliance on markets, private allocation, and contracting. Economic activity is largely determined by the forces of supply and demand, acting to a large degree in a selfregulating fashion.

However, markets are never freestanding. Effective competition in markets requires considerable attention to the codification and enforcement of the 'rules of the game' if anti-competitive and arbitrary behaviours are to be avoided. As already explained only state can provide these institutions. It is in this context that the state will always be an important constitutive element of any form of market governance.

\section{WHAT CONSTITUTES 'GOOD GOVERNANCE'?}

Lack of transparency in governance often leads to wrong political, social and economic decisions many of which affect Civil Service Reforms. Having defined governance and the modes by which it may be executed, the next challenging task is to address the issue of what constitutes 'good governance'. In line with the definitions of governance above, 'good governance' can be said to materialise if the state is able, through the power and authority vested in it, to allocate the nation's resources, and coordinate economic activities in an optimal manner. The notion of optimality connotes efficiency and effectiveness. It means that governance is conducted within the framework of effective rules and policies that underpin social harmony and sound development. In the context of state governance, good governance implies the capacity to formulate and implement sound economic policies, to institute effective legal institutions, to ensure public oversight and participation of civil society, and to have in place a credible civil service that provides citizens with an acceptable level of public services in an effective and efficient manner.

These constituents of good governance must, however, be gauged against certain predetermined criteria. According to Soesastro (2000), good governance is widely identified with the following attributes: transparency, accountability, efficiency and fairness. These are the ground rules of governance, which must be used to assess governance outcomes. Therefore, good governance does not only mean that the state 
operates effective policies and laws, but it also means, and more importantly, that it executes those policies and laws of the state in a transparent, accountable, predictable, efficient and fair manner.

\section{CIVIL SERVICE REFORMS}

Civil Service Reforms need to be an integral part of good governance processes if sustainable solutions to currently existing issues within the ambit civil services delivery are envisaged.

Within this context, there seems to be some justification for the perception that civil service reforms may be part of a mainstream agenda in Pakistan. This is evidenced by the initiation of processes such as the creation of a Committee for Civil Service Reforms, the establishment of a Civil Service Reform Unit in the Establishment Division, launching of the Professional Development Agenda and the more recent announcement of the reform package for introducing good governance in the country by the Ministry of Law and signaling the importance of this area of reform by soliciting help from the multilateral development agencies. Within this context, five points are worthy of consideration.

Bridging the Colonial-contemporary Lag: Replica on the colonial system, the core functions of Pakistan's civil services are administrative control, collection of revenue, exercising control through regulatory checks and in the case of its expanded definition to public services, active engagement in service delivery.

Exceptions notwithstanding, this model has little relevance to the problems of the public sector today which relate to harnessing the entire resources of the economy towards the goal of development. The public sector's limitations-owing to lack of resources and management issues-therefore underscore the need to develop interface arrangements, with organisations that could facilitate achieving this goal. Such interface arrangements, which have to do with establishing partnerships with the private sector for providing sustainable outcomes warrant a paradigm shift in reconfiguring the role of the public sector. This would entail 'exercising administrative control' through participatory decision-making in evidence-based frameworks, 'enforcing regulation' through setting of standards, an unbiased approach to ensuring compliance with these standards and assurance through strengthening peer organisations as we move to new models of financing and delivering services and implementing frameworks for public-private partnerships.

This would require major institutional changes in the present arrangement of civil service operations. Reconfiguring to meet this goal is the first challenge that the civil service reforms will have to address.

The Incentives-accountability-performance Nexus: Many a times, civil service reforms are considered as being synonymous with incentive building. Clearly incentives-albeit linked to performance-must be a priority to bridge the current disparity between the current public-sector salaries and the public-sector-acceptedmarket-rate for professionals, which is evidenced by what consultants 'within' the public sector are offered. However, it must be recognised that lack of capacity is clearly a constraint on the ability to act on these incentives. This highlights the need for instituting appropriately tailored capacity-building programs in tandem with Recruitment, 
Promotion and Pay and Pension Reforms currently on their way to being implemented. However, capacity building must be needs-based and targeted. The current three-pronged capacity building initiatives inclusive of the Professional Development Programme, the Executive Development Programme and revamping of the existing training institutions must pay careful attention to the local context of capacity building at the strategic and operational levels.

Building capacity for performance must be approached in cycle with creating an environment to enhance performance and the incentive-performance link completed by factoring-in accountability into the equation. This highlights the needs for institutionalising transparent managerial audit within public sector institutions at various levels. Careful attention should also be paid to developing appropriate instruments for assessing performance.

Currently, the Annual Confidential Report is the chief instrument for assessing the performance of public officials in Pakistan; however it is widely perceived that it is not an effective instrument for promoting accountability and is also reportedly used as a means of exploitation.

Civil Service Reforms to Reorientate Institutional Culture: Civil Service Reforms should not just be about incentives for performance, about reforming a line for service or about compensation of bureaucrats. The reform process must focus on governance in its broader context and enhancing efficiency in the delivery of public services in a conducive institutional culture-a culture geared in the outcomesefficiency context rather than being focused on short term gains. Therefore, in addition personnel management reforms which go beyond personnel action and set standards for performance and build mechanisms for their assessment and rewards there is a need to pay attention to transparent regulation and minimising vested interests, political benefaction and interference in decisions, particularly in relation to recruitment, transfers and disciplinary actions as these are perceived as an impediment to efficiency within the system, in addition to being a demoralising factor within the public sector.

From Civil Service to Public Service Reforms: The current focus on 'civil servants' within the context of 'service reforms' is understandable given that it is seen as an instrument for mainstreaming second generation macro-economic reforms. However if this is to translate into improved social services delivery, other cadre and ex-cadre categories of public servants must be brought within its ambit.

One of the challenges posed to service delivery in the area of health and education relates to human resource-low numbers for certain categories, migration of skilled workers, misdistribution of workforce, staff absenteeism, dual job holding, lack of motivation to perform and the proverbial brain drain are manifestations of the lack of economic opportunities and incentives often complicated by other factors. These must be at the heart of a strategic reform process rather than ad hoc measures.

Devolution vis-à-vis Decentralisation: Civil Service Reforms to improve governance must also have an added context given that social service delivery is now devolved to Districts Governments who have little experience of such responsibility in the past. This underscores the need for the reform efforts to pay close attention to two processes. In the first place, granting district autonomy and authority should proceed on a 
sliding scale with capacity as a due consideration. In the second place, it is important to build appropriate safeguards against several issues which have been brought to attention during the initial years of implementation of the Local Government Ordinance of 2002. For example, Provincial Governments still retain influence over establishment decisions and have considerable de facto control over recruitments, career management, transfers and termination. It has also been shown that political and administrative decentralisation' has also paradoxically created 'centralisation' of some functions within the district itself as the DCO now has centralised control over all the staffing decisions vis-à-vis EDOs. In addition discrepancies in reporting relationships are also worthy of note in the context of the need to address them.

Many reforms measures are presently on their way to being structured and implemented in many sectors - of these the Police Reforms, Judicial Reforms, and reforms introduced by the Public Procurement Regulatory Authority and the National Anti Corruption Strategy have been announced and there may be others, in the pipeline. A reform agenda in the health sector has also been tabled by the Pakistan's Health Policy Forum. However it must be clearly understood that the success of all these reform measures and others that may be in the pipeline will depend not only on the manner in which they pay due attention to human resource solutions-within the civil service-but also within the broader context of human resources.

\section{Rationale and Objectives of CSR}

The overall objective of Civil Service Reform (CSR) is to improve the efficiency and effectiveness of the public sector. Since civil servants (and other public employees) are ultimately responsible for delivering government services, and since these workers constitutes a sizeable proportion of government expenditure, CSR focuses special attention on-but is not limited to-human resource management (HRM) activities.

Many large-scale CSR initiatives are motivated by a desire to reduce or contain the public-sector wage bill in order to:

(a) Free up resources for other governmental objectives (i.e. direct transfers of wealth, or investments in social and physical infrastructure).

(b) Reduce government deficits.

(c) Improve service delivery.

(d) Create a more welcoming environment for private sector activity.

A second major objective of CSR is to improve the motivation, skills and effectiveness of the government workforce. International experience shows that poor HRM policy, procedures or practice can result in the wrong quality or quantity of staff, low levels of staff morale, high incidence of absenteeism and turnover, and poor individual and departmental performance. Therefore, HRM reforms have become an integral component of comprehensive CSR initiatives.

A third type of objective of CSR is to improve the quality of performance and the effectiveness of the public administration as an instrument for (changing) policies:

(a) Make public sector agencies more responsive to the needs and views of citizens. 
(b) Make public sector agencies more directly accountable for their performance and/or more manageable and flexible.

\section{Public Opinion of Civil Services}

The common man in most countries perceives the civil services system to be inefficient, corrupt, lacking in innovative abilities and unwilling to change. The general perception of civil service in Asia is depicted in the following table:

Public Perceptions of Civil Service in Asia ${ }^{2}$

\begin{tabular}{ll}
\hline Country & Public Perceptions of Civil Service \\
\hline Bangladesh & Civil service is inefficient and ineffective, inadequately representative, \\
& non-responsive to social and political demands, unfair and unhelpful to \\
& clients, unaccountable for its actions, overly cautious in handling \\
& administrative business, inclined towards unethical practices, overpaid \\
& for the work it does, overstaffed and unreliable. \\
& Civil servants as 'status quoists', and lacking in innovation, initiative, \\
& empathy or the drive for change. The service is perceived to be \\
India & overstaffed, wasteful, over-cautious, unfair, non-responsive and corrupt \\
& (also see Table 1). \\
Japan & Although the Japanese civil service has made important \\
& contributions to the industrialisation of the country and is widely \\
& respected overseas as hard-working and loyal, public opinion is still \\
& critical of the service because domestic public expectations have \\
& outstripped civil service performance. Corruption scandals involving \\
& senior Japanese bureaucrats have also damaged the public image of \\
the civil service. & \\
The civil service was 'the hero' of Korean industrialisation and \\
Korea & liberated the people from poverty, but the public has not given much \\
credit to the heroes. Although civil servants are neither lazy nor \\
wasteful, they are inefficient and not effective enough to please the \\
public. The civil service is also overstaffed. With economic \\
development has come rising expectations for service and probity that \\
the civil service has thus far been unable to meet. \\
A growing cynicism about the way graft and corruption in the civil \\
service with the authorities lacking the political will to fight corruption. \\
Corrupt officials are given an easy way out and those guilty of \\
Philippines \\
corruption continue to hold high office. \\
Public's image of civil services in relatively of low esteem as compared \\
to other professions.
\end{tabular}

${ }^{2}$ Burns, John P. and Bidhya Bowrnwathana 2001, Civil Service Systems in Asia. Cheltenham, UK: Edward Elgar. 


\begin{tabular}{lc}
\multicolumn{2}{c}{ Public's Image of Various Professions in China $(\%)^{3}$} \\
\hline Profession & Very Good (\%) \\
\hline Scientific and Technological Personnel & 50.1 \\
Teacher & 44.6 \\
Military Cadre & 42.6 \\
Armed Police & 41.6 \\
Lawyer & 38.5 \\
Airline Worker & 35.7 \\
Author & 35.1 \\
Discipline-inspection Cadre & 34.6 \\
Medical Personnel & 34.3 \\
High-level Cadre & 31.4 \\
Customs Officer & 28.5 \\
Public Security Cadre & 28.5 \\
Railroad Worker & 26.9 \\
Office Management & 26.1 \\
Reporter & 26.1 \\
Party Cadre & 22.7 \\
Government Cadre & 22.8 \\
Mid-level Cadre & 20.4 \\
Basic-level Cadre & 18.8 \\
Tax Collector & 12.6 \\
Industry/Commerce Administrative Personnel & 9.8 \\
\hline
\end{tabular}

\section{Civil Service Transformation Model ${ }^{4}$}

The nature of the Civil Service of a country and analyse the change being created by reforms. It has two core dimensions: state-society relations and the key characteristics of Civil Service systems. Each of these dimensions in turn are defined in terms of two parameters:

State-society relations are expressed according to the degree of institutionalisation of the nation state, measured by its degree of cohesiveness and shared commitment to basic procedures and practices; aggregated public attitudes to the state. Are public attitudes mostly pro-state, that is, does the public generally believe in the legitimacy of state competence? Or are they more anti-state, that is, does the public believe that strict limits should constrain the domain of government action.

The civil service system can be expressed in terms of:

(a) the relative value placed by the service on process or outcomes; and

(b) the degree to which the service is politicised or managed with professionalism.

${ }^{3}$ Burns, John P. 2001, 'The Civil Service System of China: The Impact of the Environment', in Burns, John P. and Bidhya Bowornwathana. Civil Service Systems in Asia. Cheltenham, UK: Edward Elgar.

${ }^{4}$ Morgan, E. P. 1996. 'Analysing Fields of Change: Civil Service Systems in Developing Countries', in Bekke, A. J. G. M., J. L. Perry and Th. A. J. Toonen (eds). Civil Service Systems in Comparative Perspective. Bloomington: Indiana University Press, pp. 227-46, cited in Burns, John P. and Bidhya Bowornwathana. 2001. Civil Service Systems in Asia. Cheltenham, UK: Edward Elgar. 
Superimposed on one another, the two dimensions and four parameters produce a four-part box for assessing the change necessary to reform the civil service of a country. The four quadrants in the box represent:

Civil Service Transformation Model

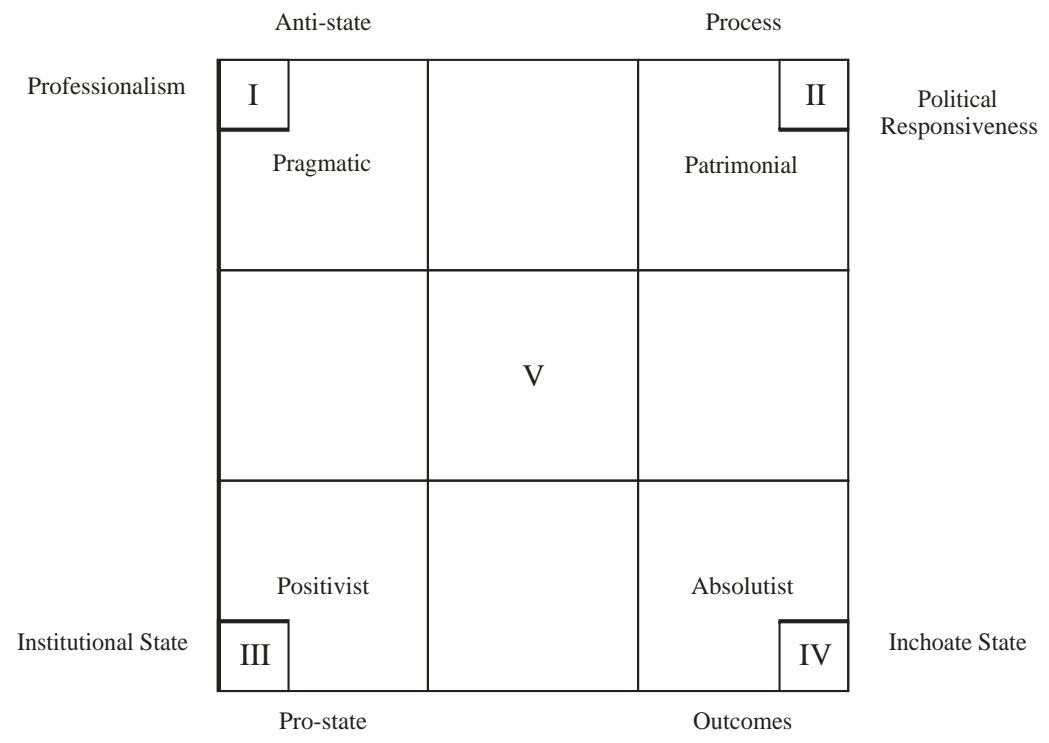

Quadrant I-the pragmatic field-The state is highly institutionalised, public opinion is basically anti-state and the civil service is more professional and process oriented (example, the USA).

Quadrant II-the patrimonial field-The state is relatively 'inchoate' or noninstitutionalised, public opinion is still basically anti-state and the civil service is more politically responsive, but still process oriented (example, Nigeria).

Quadrant III-the positivist field-The state is relatively highly institutionalised and the public shares a more pro-state orientation, while the civil service is more outcomes oriented and professional (examples, France, Japan and South Korea).

Quadrant IV-the absolutist field-The state is less institutionalised, but the public is relatively more pro-state while the civil service is more outcomes oriented and politically responsive (China during 1949-66).

As a country undertakes reforms, the state-society relations change and as civil services become more professional, countries move from one field to another. Moreover, variation within fields is great. Marginal cases in each of the four fields tend to cluster towards the middle of the respective continua, suggesting that they could be in one of several fields.

\section{CIVIL SERVICE REFORM UNIT}

The Government of Pakistan has an ambitious and comprehensive program of reforms to accelerate growth and poverty reduction. A Civil Service Reform Unit (CSRU) has being created to oversee the implementation of reforms. The government has 
also amended the Federal Public Service Commission Ordinance to institutionalise meritbased, transparent recruitment for the civil service. While there has been some improvement, as a result of on-going reforms, Pakistan's civil service still requires systemic renewal and structural changes.

The creation of the political structure for devolution began in 2001 with the creation of a new local government structure consisting of over 6,400 new indirectly elected local governments. Administrative reforms include the creation of district governments with the District Coordination Officer (DCO) established as the highestranking civil servant in the district. District governments have been given functional responsibility for delivering key services, including education and health care along with the rights to raise additional revenues. While there are early signs that devolution is beginning to yield positive results, it is also clear that much remains to be done.

Weaknesses in tax policy and administration have long been identified as being among Pakistan's most serious challenges. Collusion between taxpayers and tax officials has been pervasive and facilitated by the discretionary powers of tax officials, complex tax rules, and weak supervision of staff. A fundamental change in tax policy began in July 2002 with the introduction of a system based on Universal Self Assessment with risk-based audit and record keeping to minimise taxpayers' interaction with tax officials.

Beginning with a highly publicised effort to prosecute high profile cases of corruption, including public officials and the influential, the government has made anticorruption a key element of its governance agenda. Building on these efforts, a comprehensive

National Anti-Corruption Strategy (NACS) was approved in 2003, with three elements: education and awareness to reduce tolerance for corruption; prevention through improved management and governance to reduce the need and opportunities for corruption; and better accountability mechanisms to further strengthen deterrence.

The government's reform programme in public financial management is well underway. The timeliness of financial statements has improved along with the reliability of data. There has also been considerable progress in improving the timeliness of audits over the past two years-reports are available within one year of the end of the fiscal year. While demonstrating progress on the above points, less progress has been demonstrated in the development of Public Accounts Committees (PACs)—especially at the National level, and in addressing the shortcomings in public procurement

The Government of Pakistan has contracted a US\$ 55 million IDA Credit under the Public Sector Capacity Building Project. (PSCBP) The project has several subcomponents, out of which the largest is Establishment Division's sub-component. In order to implement the sub-component of Establishment Division, a Civil Service Reform Unit (CSRU) has been established within the Establishment Division.

The Unit will also serve as Secretariat to the Cabinet Committee on Civil Service Reforms which will oversee GOP's comprehensive civil service reform programme. CSRU will formulate and present technical recommendations in order to support civil service reform through outsourcing technical studies and organising Seminars/Workshops by involving all the stakeholders at the provincial and national level to develop consensus on various aspects of Civil Service Reforms. 


\section{Barriers to Civil Service Reform in Pakistan}

In general, the more comprehensive and complex the process of reform undertaken, the greater the management capacity required for successful implementation. However, since such management capacity is often in short supply-and typically in great demand-securing the involvement of government officials with the requisite managerial expertise can be difficult.

To succeed, civil service reforms require some measure of support and involvement from current civil servants. Yet the uncertainty and potential loss of privileges which are associated with civil service reform initiatives can cause civil servants to resist (or not actively cooperate) with the process of planning and implementing reforms.

Reform initiatives are often viewed as an outside imposition, and resisted as such, especially when they are associated with larger structural adjustment programmes required by international lending authorities (e.g. World Bank and IMF).

\section{Enabling Conditions for Civil Service Reform}

Explicit political support and involvement from high-level government officials for the duration of the reform process is required. Reform initiatives are more likely to succeed if led by a reform implementation agency with adequate prestige, authority, skill and technical competence.

Reform programmes are more likely to be successful when defined in terms of specific goals and pursued on the basis of a well-defined strategy which pre-specifies the means, timing and sequencing of actions and which honestly reflects institutional realities and constraints.

Effective communication with all key actors and stakeholders (including citizens) who have an interest in the process or outcome of civil service reform is critical.

Reform initiatives must be grounded and led by the experience and expertise of local authorities to be successful. While external parties may lend critical advice and technical assistance, reform initiatives that are not "owned" by local authorities are unlikely to succeed or be sustainable.

\section{Main Elements of Civil Service Reforms}

The main elements of civil service reform centred on:

(a) Changing the role of government from regulator to facilitator, with an emphasis on refocusing and narrowing of overall responsibilities.

(b) Identifying regulatory constraints to investment and other economic activities.

(c) Improving delivery of services to the people, and making efforts for simplified rules and procedures, decentralisation and delegation.

(d) Identifying alternate systems of delivery arising from the delineation of the areas to be vacated by government, by increasing attention to the scope for privatisation, various forms of public-private partnerships, and formalised consultative mechanisms with various stakeholders.

(e) Emphasising the entrepreneurial role of the government, through commercialisation of infrastructure, laying down performance standards, 
costing and marketing of government products and services, and delivery of services at the operational level.

(f) Matching revenues and costs, improving financial planning and management systems, securing value for money in government.

Shift in the Government's Role

\begin{tabular}{ll}
\hline From & To \\
\hline A Major operator in many sectors of the & $\begin{array}{l}\text { A prudent facilitator of private sector } \\
\text { activity in sectors best operated by the } \\
\text { private sector, and provider of services in } \\
\text { other sectors }\end{array}$ \\
A regulator and controller of most & $\begin{array}{l}\text { An enabler of market-based development } \\
\text { through conducive deregulated policy }\end{array}$ \\
economic decisions in many sectors (for & environment \\
example pricing policies) & $\begin{array}{l}\text { Enabling, empowering and ensuring } \\
\text { participation of local administration and } \\
\text { direct top-down administration antralised decision-making }\end{array}$ \\
\hline
\end{tabular}

\section{Recruitment and Retention of Personnel}

The effective performance of a civil service depends on sound recruitment, selection and retention practices. Low morale, high turnover, extreme civil service wage bills, and poor service quality are common to government administrations that fail to attract, retain and motivate high-quality civil servants.

\section{HRM Reform through Decentralisation}

To avoid the inflexibility and delays common to many centralised civil service personnel systems, some governments decentralise various human resource management (HRM) responsibilities to individual ministries, newly established Executive Agencies or regional government entities.

Successful devolution of Human Resource Management activities can lead to:

(a) Reduced delays in recruitment.

(b) Better matches between candidates and specific departmental needs.

(c) Increases in staff retention and reductions in absenteeism.

(d) Improved staff and management morale.

(e) Increased cost-effectiveness in meeting organisational objectives.

(f) Key Challenges and Trade-offs.

It is difficult to strike an appropriate balance between consistency in HRM practices across government agencies and the need to provide greater flexibility to individual agencies. It is important to recall that traditional, centralised recruitment and hiring practices were designed to limit corruption and patronage and to cultivate an esprit de corps among civil servants. However, the tight regulations and procedures used to meet these objectives sometimes result in long delays, rigidity, and failure to meet operational needs of the employing departments or the career needs of individual 
candidates and employees. These limitations, in turn, can lead to inefficiencies and poor service delivery. At the other extreme, complete decentralisation of HRM functions can inhibit cross-departmental movement of personnel, result in variability of standards and employment terms, and potentially permit the continuation of biased hiring or promotion practices.

One common mechanism for achieving balance in this regard is to gradually devolve HRM responsibilities to separate ministries or Executive Agencies within guidelines established by a Federal Public Service Commission, or its equivalent.

When decentralising HRM functions, two additional challenges should be kept in mind. First, going to the "market" to recruit mid and upper level managers may be costly and difficult in Pakistan, especially where international donors have "bid-up" salaries for (the limited number of) talented professionals who possess the skills and desire to work in the public sector. In some developing countries, doing away with the enforcement of uniform recruitment practices may create additional opportunities for patronage and corruption.

\section{Merit as the Basis of Recruitment, Selection, and Promotion}

Merit-based recruitment and promotion involves the specification of objective criteria related to qualifications, experience and ability to achieve organisational goals as the basis for decisions concerning entry into (or advancement within) the Civil Service. Merit-based systems strive to ensure the recruitment and selection of the "best" and most capable candidates, thereby assisting efforts to attract, secure and retain professional, high-quality civil servants.

Merit-based systems share two basic features-transparency and contestability. A merit system fulfils the requirement of transparency when the criteria used for selection and promotion decisions are made known to the public and are open to scrutiny. The condition of contestability is established whenever mechanisms exist that permit perceived violations of merit-based hiring or promotion decisions to be reviewed and challenged.

A hiring or promotion decision should be based on merit if it meets all of the following criteria:

(a) An assessment is made of the relative suitability of the candidates for the duties, using a competitive selection process;

(b) The assessment is based on the relationship between the candidates' workrelated qualities and the work-related qualities genuinely required for the duties;

(c) The assessment focuses on the relative capacity of the candidates to achieve outcomes related to the duties; and

(d) The assessment is the primary consideration in making the decision.

\section{Types of Merit-based Civil Service Systems}

There are two broad categories of merit-based civil service systems-career systems and position-based systems. 
Career systems-involve the application of merit criteria at the entry point into the civil service. To enter a closed career civil service system applicants are required to take a standardised entrance exam and/or be in possession of certain (academic) credentials or professional experience. These "screening" techniques identify candidates who possess the base level of knowledge and aptitude deemed necessary for successful performance as civil servants. In a traditional career civil service system, competitions for most middle and senior-level positions are closed to candidates outside the civil service.

Position-based system-Under this system, recruitment and hiring practices aim to ensure that the best-suited candidate for each position is found and selected, whether from within or outside the civil service.

Many countries are moving to develop hybrid system which combines elements of both career, and position-based civil service systems.

\section{TRAINING AND CAREER MANAGEMENT}

Effective training, professional development and career path management for civil servants improves professional competence, employee morale, and organisational learning. Consequently, successful reforms in these areas can substantially increase the effectiveness and efficiency of the public service.

The link between staff training and development and the overall effectiveness of the public service is made more salient by the following trends:

(a) The accelerating rate of organisational and technological change requires staff to acquire new skills and attitudes throughout their career in the public service.

(b) Pressure to reduce public sector wage bills can lead to hiring freezes or reductions in personnel. Staff that remains after the implementation of wage control initiatives is often required to assume additional responsibilities and perform a broader range of tasks. To do so effectively, staff may require extensive training, coaching and mentoring.

(c) Rising public expectations of the public serve require staff to possess sharper technical skills and more responsive, service and outcome-oriented attitudes.

(d) Continuing public and fiscal pressure for demonstrated efficiency improvements on the part of the public sector will require staff at all levels to make use of business planning and strategic management skills.

(e) Providing opportunities for professional development and training increases the overall attractiveness of working in the public sector and thus assists recruitment and retention efforts.

\section{On-the-Job Training and Professional Development}

Opportunities for training and professional development can frequently be provided to staff "on-site" or within the context of their everyday jobs. Rotational assignments, peer reviews and managerial briefings are three common types of on-the-job training made available to staff by governments around the world. These formalised learning experiences are distinguished from the informal learning which takes place in the normal course of one's daily work by the fact that acquiring and assimilating new 
knowledge and skills is a primary (as opposed to secondary or incidental) objective of these assignments.

\section{Rotational Assignments}

By exposing staff to new activities and experiences, rotational assignments allow staff to develop new skills. Rotational assignments also permit staff to develop broader professional networks, a process which can lead to personal professional development and improved organisational performance. Although rotational assignments are traditionally confined to the public service, some governments have developed crosssector exchange programmes. A private-public sector exchange programme permits civil servants in Japan to spend three years in the private sector, while a similar programme exists in Korea.

\section{Peer Reviews}

Participating in and being the subject of peer reviews provides an opportunity for staff to identify individual and organisational "deficiencies" that require adaptation and learning. While peer review may focus on diagnosing areas for improvement, the challenge of appropriately evaluating one's peers is in itself a unique opportunity to refine communication, analytical and social skills.

\section{Briefings}

Whether they are of a technical, strategic or procedural nature, effective briefings by management often aim to further develop staff's ability to integrate process and apply information and knowledge.

\section{Ensuring a Corruption-free Civil Service}

Corruption prevails where there is ample opportunity for corruption at little cost. Incentive structures encourage corrupt behaviour. Anticorruption strategies therefore aim at reducing the opportunities for corruption while increasing the expected cost, i.e. the risk of being caught and severely punished. ${ }^{5}$

Applying this to anticorruption programmes means to move beyond public administration and financial management reform to look at broader structural relationships, including the internal organisation of the political system, the relationship between the state and firms, and the relationship between the state and civil society.

There is a strong correlation between the extent of government involvement in the economy, and the amount of corruption. Also, the extent of corruption in a country is governed by the structure of its public services, particularly their selection and promotion processes, and their wage scales comparative to the private sector. According to a 1996 survey of two thousand enterprises across forty-nine countries, a higher incidence of corrupt practices are found in countries with more regulatory and bureaucratic requirements for business.

${ }^{5}$ Marong, Alhaji B. M. 2002. Toward a Normative Consensus Against Corruption: Legal Effects of the Principles to Combat Corruption in Africa. Denver Journal of International Law and Policy 30:2, 99-129. 
The more administrative discretion officials enjoy in approving regulatory requirements such as the issue of permits, licenses, or grants of fiscal exemption to business, the more the likelihood of corruption.

Investors view bribery as a private tax on their investment, and tend to shy away from jurisdictions with high rates of "private taxation".

Bribery increases the transaction costs of doing business in particular jurisdictions. The effect has been lower inflows of foreign investment to countries with high rates of corruption.

\section{Impact of Corruption on Entrepreneurship and the Economy}

There is a negative correlation between the amount of corruption and the level of investment in a country. A country which improves its standing on the corruption index by one standard deviation (on a scale of 0 to 10 where 0 is the most corrupt and 10 the least corrupt), will experience an increase in its rate of investment by about four percentage points. The improvement by one standard deviation in a country's corruption index would translate to an annual growth rate of over half a percentage point in per capita Gross Domestic Product. ${ }^{6}$

Corruption leads to negative consequences for both producers and consumers. Firms that have to bear the cost of corruption are unable to shift the entire burden of corruption to the consumers since the latter resist such a move by reducing the amount purchased. Thus the total quantity sold declines and the price rises. Some or all firms are forced to reduce production while some others close down altogether to being about a reduction in total production. A part of consumer, as well as producer surplus are taken over by corrupt officials. Therefore, both consumers and firms share the cost of any bribes.

Public servants often customise government policies to facilitate receiving bribes or other illicit payments. Thus, government policy and expenditure are prioritised towards capital-intensive infrastructure, defence, and cognate supply type contracts that offer opportunities for rent-seeking and kickbacks, instead of socially desirable and needed health, education an public welfare projects.

As a public office offers ample opportunities to get rich quick there is stiff competition to gain such an office and much effort and material resources are be spent in this pursuit.

Singapore-In Singapore the anti-corruption strategy is based on both the incentives and reducing opportunities to get corrupt. The incentives focus on high salary structure, and deterrent through strong legal provisions. The Prevention of Corruption Act (POCA) provides to the government additional powers of arrest, search of arrested persons, and examination of bank accounts and other assets of those civil servants under investigation.

Hong Kong-Hong Kong has set up an Independent Commission Against Corruption (ICAC) which has wide investigative powers and its officers cannot be transferred to any other department or post. Its advisory committees are all chaired by eminent non-officials and all reports are made public. The ICAC sponsored a massive,

${ }^{6}$ Taslim, M. A. 1994. Corruption and Entrepreneurship. The Journal of Bangladesh Development Studies 22:1, 117-31. 
well-education campaign against corruption. Even concerts and sporting events, fostering social interaction, have anti-corruption as the main theme.

India-India has set up the institution of Lokpal to examine the cases of corruption at the top. But most of the existing State laws authorise the Lokpal merely to tender advice and the government is not bound to accept the advice.

\section{CONCLUSION}

Pakistan's civil service has been following the British model, but now it is being professionalised. Rank-based system, the generalists are preferred to specialists, and lifetime employment is provided to its incumbents.

The common man in most Asian countries perceives the civil services system to be inefficient, corrupt, lacking in innovative abilities and unwilling to change. Lack of transparency often leads to wrong socio-economic and political decisions, many of which affect Civil Service Reforms.

Good governance involves promoting the rule of law, tolerance and a transparent socio-economic and political processes and an independent judiciary. Above all, good governance means respect for human rights.

There is a need to change the role of government from regulator to facilitator, with an emphasis on refocusing and narrowing of overall responsibilities, and improving delivery of services to the people, and making efforts for simplified rules and procedures, decentralisation and delegation.

A Civil Service Reform Unit oversees the implementation of reforms in civil service, while the Federal Public Service Commission is entrusted to institutionalise merit-based, transparent recruitment for the civil service.

The other facet of civil service is the strong correlation between the extent of government involvement in the economy, and the amount of corruption. Also, the extent of corruption in a country is governed by the structure of its public services, particularly their selection and promotion processes, and their wage scales comparative to the private sector.

Civil servants need effective training and career development, which would result in better organisational and individual performance. The structure of civil service performance appraisals should be around core competencies, with specific goals for the coming review period to increase core competencies.

Civil servants need to be retained on the basis of the adequacy of their performance and inadequate performance should be corrected. Those who cannot or will not improve their performance should be separated from service.

Civil Servants are to be protected against arbitrary action, personal favouritism, or coercion for partisan political purposes; prohibited from using their official authority or influence for the purpose of interfering with or affecting the result of an election or a nomination for election; and be defended against reprisal for the lawful disclosure of information which the employees reasonably believe evidences a violation of any law, rule, or regulation. 